\title{
The Relationship between Delay in Announcing Quarterly Forecasts of Annual Earnings and the Type of Earnings News
}

\author{
Mahdi Moradi, Mahdi Salehi ${ }^{1}$, Seyyed Saeed Mehrdad Ayask
}

Ferdowsi University of Mashhad, Iran

\begin{abstract}
The current study aims to examine the relationship between delay in the announcement of quarterly forecasts of annual earnings and the type of earnings news in a unique context. Running a multiple linear regression on data collected from Rahavard Novin software and the companies' financial statements, is the method of this study to investigate this relationship. Consistent with the pattern of good news early, bad news late, it was found that there is a positive relationship between the bad news type and the amount of delay in announcing quarterly forecast of annual earnings; so that the firms with negative adjustments in earnings forecast (bad news), on average, have 12 more days delay in the announcement. Considering other variables showed that as coverage percentage - a sign of success - increases, the amount of delay in announcing earnings forecast decreases, but companies with losses per share, on average, have an additional delay of about 6 days. The results obtained indicate that at least, in some industries there is certain time for reporting. Finally, it became clear that in the period after the adoption of the new disclosure instruction, despite the increased deadline, the amount of delay in earnings announcement has declined by about 2 days. In this study, for the first time in Iran, one of the company's financial news (quarterly forecasts of annual earnings), have been classified into good and bad, based on comparison with the market expectation, and the relationship between the news type and the amount of delay in announcing the news, has been examined.
\end{abstract}

Keywords: Reporting delay, Good news, Bad news, Annual earnings per share quarterly forecast.

\section{Introduction}

The main qualitative characteristics associated with the content of information are 'relevance' and 'reliability'. If financial information is not relevant and reliable, it will not be useful. For information to be relevant, timeliness of its disclosure is a necessity. Reporting delay reduces the usefulness of information for users. Also, release of information as earliest time as possible, can prevent information from leaking to those close to the company and thereby reduce information asymmetry among the market participants. Considering the fact that time of disclosure depends on the corporate management, several studies investigated the factors affecting the decision on the timing of disclosure by company managers. A factor that has attracted the attention of researchers, particularly is the relationship between the type of news (good news versus bad news), and the timing of disclosure of the news. In the disclosure literature, generally, it confirmed that companies tend to announce good news, early and bad news, late. According to a Tehran Stock Exchange (TSE) instruction, listed companies within the organization should announce their quarterly forecast of annual performance, based on 3, 6, and 9-month performance. On this basis, and given that in Iran, providing management forecasts of annual earnings per share is mandatory, at the end of each quarter, and within a certain deadline, the present study is to investigate the relationship between the type of earnings news and the amount of delay in announcing the earnings forecast per share.

The requirement to announce an earnings forecast, on a regular basis, and at the end of each quarter, has provided a unique opportunity to conduct research on the reaction of companies and the market, in response to this requirement. Based on the authors' findings, there is no such requirement in any other country. It suggested that the motivation of the Stock Organization for establishing this requirement

1 Corresponding author: Ferdowsi University of Mashhad, Faculty of Economics and Business Administration, Azadi Square, Vakilabad Bolvard, Mashhad City, Khorasan Razavi Province, Iran, E-mail: mahdi.salehi@um.ac.ir

Received: $22^{\text {nd }}$ October 2012; revised: $14^{\text {th }}$ December 2012; accepted $5^{\text {th }}$ January 2013 
is to move in line with the overall goal of improving the stock market transparency, and timely and pervasive access to information for users and investors, before and after transaction, (the information disclosure regulation for listed companies in the TSE, enacted in 2002). This study contributes to advances in accounting theory as to pragmatics aspect, because it tries to assess the reaction of the providers of the information themselves to the information provided.

\section{Background and hypothesis development}

\subsection{Good news early, bad news late, pattern}

Studies conducted since of the early 1980s, investigating the timing of earnings announcement, showed that corporate managers tend to release good news early and delay the announcement of bad news (Roychowdhury and Sletten, 2012; Cullinan et al, 2012; Senguptha, 2004; Bagnoli et al., 2002; Haw et al., 2000; Begley and Fischer, 1998; Damodaran, 1989; Kross and Schroeder, 1984; Chambers and Penman, 1984; Kross, 1982; Givoly and Palmon, 1982; Kross, 1981). Apparently first Beaver (1968) suggested that the lower than expected earnings (bad news) may be reported later than the higher than expected earnings (good news). Based on this, Kross (1981) conducted empirical research on the relationship between profitability and earnings announcement delay, which his result confirmed this subjective idea that bad earnings news is released late. Kross (1982) investigated the market perception of the delay in reporting and tried to understand whether market reacts the timing of annual earnings announcement. The results showed that the stocks of companies that released their annual reports later (including the holder of good news and bad) had lower abnormal returns than the companies did release their reports earlier than the expected time. Findings of Givoly and Palmon (1982) also confirmed this result. Chambers and Penman (1984) observed the differential positive Abnormal returns associated with an earlier than expected reports, concluded that when companies have good news, they publish their reports earlier. These three researches measured the market reaction to the delay, regardless of the type of earnings news.

Unlike previous studies, that examined only the announcement of annual earnings Kross and Schroeder (1984) investigated the relationship between the timing of quarterly earnings announcement (early or late) and the type of reported earnings (good or bad). They also investigated the differential effect of late earnings news on stock returns for quarterly announcements. The results of Kross and Schroeder (1984) showed that the quarterly earnings announced earlier than expected (1) contained better news, and (2) had higher abnormal returns than late announcements. Senguptha (2004) also investigated the factors affecting the timing of quarterly earnings announce- ment. The results showed that, bad earnings news had a significant positive effect on the delay in the announcement of quarterly earnings.

Bagnoli et al. (2002) reported that managers who announce their earnings later than the expected date, eventually, their declared earnings is, on average, one percent less than the consensus forecast, per each day of delay, which shows that when earnings announcement is later than expected, it usually contains bad news and the further the delay, the worse is the news.

In the opposite direction with the results of previous studies Chen and Mohan (1994) have suggested that companies that report too early disclose bad news, a behavior that according to Skinner (1994) could be a preemptive action against the possible litigation risks.

The findings of Aubert (2009) from French companies are consistent with this interpretation. His findings indicated that there was a significant negative relationship between bad news and delay in announcing annual earnings.

Chen and Mohan (1994) conducted a survey on top management about the issues related to the timing of earnings announcement, and it became clear that about $50 \%$ of responding companies had a fixed timetable for earnings announcement. Companies that altered the reporting timing suggested that the level of unexpected earnings had the most effect on the decision about earnings timing. Lower than expected earnings (bad news) was more likely to cause a change in timing compared to higher than expected earnings (good news), and the possibility of changing the date (day) of announcement was more than changing the hour of announcement during a day.

Most of previous studies had pointed out that a pattern of "bad news, late," existed. However, consistent with the pattern of "good news, early," findings of Guay and Verrechia (2007) indicated that it is more likely for good news, to be announced early than bad news, and this is due to the inherent conservatism of financial reporting, that is, bad news is usually recognized and reported earlier than good news in the audited financial reports. This asymmetric recognition leads management to voluntarily disclose good news earlier than bad news, to be a compensation for the existing bias toward bad news in financial reporting standards.

Underlying patterns in the timing of earnings announcement are not fixed, and by the time, they change with the change in information environment and the advancement of communication and changes in legal and litigation environment. Begley and Fischer (1998) investigated whether or not the increased litigation risk in the United States during the 1980s, has been deleted the pattern of good news early, bad news, late'. Using a sample of the 1980s and early 1990s, they found strong evidence that despite the benefits and costs of delay in reporting bad news has changed but the pattern of timing still exist.

Philipich (2009) also investigated the effect of changes in the legal environment on the managers' disclosure strategies, particularly on the pattern of "good news, early, bad news, late". He concluded that the increased pressure 
and litigation risk and potentially huge losses resulting from these risks, has reduced the directors' dare to delay news announcement and It has weakened the relationship between news type and amount of delay in announcing the news, and they inform us of the likelihood of its disappear in the long term. However, Haw et al., (2006) reported that although new legislative requirements on disclosure process significantly reduced the delay in reporting but the pattern of good news early, bad news late, still maintains in China.

\subsection{Determination of the type of earnings news}

To determine the type of earnings news as to being good or bad, researches have typically compared actually announced figure with market expectation, to classify the announced earnings as good or bad. Earnings higher than market expectation (positive unexpected earnings) are considered good news, and lower than market expectations earnings (negative unexpected earnings), are considered bad news. However, the market expectation is measured by two criteria. To identify the market expectation, Initial researches used the random walk model (time series). In these studies, the increase in earnings compared to the previous quarter(s) or year(s) is considered good news and decrease in earnings is considered bad news (Philipich, 2009, Damodaran, 1989, Patell and Wolfson, 1982). In fact, market expectation obtained from the latest number(s) of earnings announced. However, in developed capital markets, in recent years, the more common criterion has been the mean. Median of the latest analysts' forecasts was used in some studies (Doyle and Magilke, 2012; Bagnoli et al., 2006; Begley and Fischer, 1998).

Also related to the factors affecting the timeliness of reporting, some research performed in Iran (Moradi and Poor Hosseini, 2009; Moayyeri, 2007; Sarhangi, 2001; Yaar Mohammadi, 2001). Of course, none of these researches has divided earnings into good and bad, based on comparison with market expectation. Specifically, in these studies, only the effect of net profit or loss, as good or bad news investigated on the amount of delay in reporting, that in two studies (Sarhangi, 2001; Moradi and Poor Hosseini, 2009) its effect on the delay in reporting, has been significant.

\subsection{Requirements of TSE}

In accordance with article 5 of the instruction of Information disclosure in listed companies (approved in Securities
Exchange Council, 2002) companies were obliged to announce their forecast of the annual performance based on prior fiscal year performance within at most, 30 days before the new fiscal year, and based on actual performance of each quarter, at most, 20 days after the end of the quarter. In addition, listed companies were obligated to forecast earnings per share (EPS) at the end of each quarter, at most, within 20 days after the end of the quarter. In this regard, in 25/7/2007 the TSE Board of Directors ratified the new instruction of information disclosure for companies listed in TSE. In Chapter III, Section I, paragraph 7 of these instructions, listed stock companies were obligated to announce their forecast of their annual performance based on actual performance of $1^{\text {st }}, 2^{\text {nd }}$ and $3^{\text {rd }}$ quarters, up to 30 days after the end of each quarter.

About the relationship between the type of quarterly forecasts of annual earnings news and amount of delay in its announcement, there has not been performed any research outside Iran, because, as mentioned earlier, in most countries, forecast of earnings is optional, and in such an atmosphere, discussion of the delay in its announcement, is meaningless and accordingly, in other countries, there is no study to evaluate the delay in announcing quarterly forecasts of annual earnings. Nevertheless, specifically inside the country, there is no study conducted on the delay in announcing the forecasted earnings per share. Thus, based on the results of the previous studies, and consistent with the subject of the present study, to investigate this relationship, the hypothesis of this study is formulated as follows:

$\mathrm{H}_{1}$ : There is a significant positive relationship between bad earnings news and the amount of delay in announcing the news.

\section{Research Methodology}

Target population includes all companies accepted in the Tehran Stock Exchange, and the available statistical population (the sample) for this study includes all companies accepted in the Tehran Stock Exchange that the information about their announcement of quarterly forecasts of annual earnings and their annual and interim financial statements are available.

The following criteria have been used to form the available population (the sample).

* Only firms that have issued 3,6 and 9-month forecasts.

* No forecast issued Between 3, 6 and 9-month forecasts.

* No forecast issued in two months before the end of the first quarter.

* No increase of capital occurred during the investigated year.

2 RAHAVARD NOVIN is an financial information software that collects and classifies the data from Tehran Stock Exchange. The data is provided in a technical pack and a fundamental analysis pack and more. The software is produced by MABNA CORP. Group. The website is: http://www.mabnacorp.com 
Finally, based on these criteria, 440 firm-years of 236 firms remained. The study period encompasses the years 2004 to 2010 (7 years) and the research place is TSE. By the way, to collect data, financial statements of the companies, TSE website and Rahavard Novin software ${ }^{2}$, were employed.

\subsection{Research model}

To test the hypothesis, the amount of delay in announcement forecast, has modeled as a function of factors influencing it as follows:

Where:

$$
\begin{aligned}
\text { DELAY } & =\alpha_{1}+\alpha_{2} \text { BAD }+\alpha_{3} \text { GOOD } * \% \Delta \text { EPS }+\alpha_{4} \text { BAD } * \% \Delta \text { EPS } \\
& +\alpha_{5} \% \text { COVER }+\alpha_{6} \text { SHARE }+\alpha_{7} \text { SIZE }+\alpha_{8} \text { BLOCK } \%+\alpha_{9} \text { CONSOLIDATE } \\
& +\alpha_{10} \text { LOSS }+\alpha_{11} \text { POST }+\sum_{\mathrm{k}=1}^{\mathrm{n}-1} \beta_{\mathrm{k}} \text { INDUSTRY }+\varepsilon
\end{aligned}
$$

DELAY: A numeric variable that equals the number of days between the end date of the quarter and the date of announcing annual EPS forecast based on the quarter performance.

BAD: It is a dummy variable that equals (1) if the sign of adjusted earnings per share is negative, otherwise 0 . This variable captures the relation between bad news and amount of delay in reporting the news, expected this relationship to be positive. Approval or rejection of the research hypothesis will be done based on the sign and significance level of the coefficient of variable BAD.

GOOD*\% $\%$ EPS: the Interaction of good news with the percentage of EPS adjustment that captures the effect of the magnitude of EPS adjustments on the relation between good news and the amount of delay.

BAD $* \%$ EPS: the Interaction of bad news with the percentage of EPS adjustment that captures the effect of the magnitude of EPS adjustments on the relation between BAD news and the amount of delay. Its coefficient is expected to have a positive sign.

The percentage of EPS adjustment variable (\% $\%$ EPS) is calculated by comparison of the announced EPS for each quarter with the EPS reported for the previous quarter. For the first quarter EPSs, The percentage of EPS adjustment is obtained by comparison of the last number of real earnings for the past year or the last forecast announced for the current year that is calculated as follows:

$$
\% \Delta \mathrm{EPS}=\frac{\mathrm{EPS}_{\mathrm{t}}-\mathrm{EPS}_{\mathrm{t}-1}}{\left|\mathrm{EPS}_{\mathrm{t}-1}\right|} \times 100
$$

SHARE: the natural logarithm of the average number of traded shares from the beginning of the year up to the end of the considered quarter.

BLOCK\%: The percentage of shares belonged to major owners (owning more than or equal to 5\%), at the beginning of fiscal year. Following pervious research, the two variables of SHARE and BLOCK\% control for the effect of investors' information needs or market demand on delay in reporting (Aubert, 2009; Senguptha, 2004).

SIZE: the natural logarithm of sales revenue from the beginning of the fiscal year to the end of each quarter.
Disclosure literature has consistently showed that factors of company size are related to different disclosure measures (e.g. Senguptha, 2004, Bushee et al., 2003).

CONSOLIDATE: is a dummy variable that equals 1 , if the company wwould prepare consolidated financial statements, otherwise 0 . This variable controls for the effect of accounting complexity.

LOSS: is a dummy variable that is equal to 1 , if a company reported zero or negative EPS forecast, otherwise 0.

COVER\%: controls for the effect of coverage (realization) percentage of the annual earnings forecast in each actual quarterly earnings. Success of a company in realizing a greater part of the annual earnings forecast is a sign of better performance of the company, and it is expected that the greater coverage percentage, delay in announcement of earnings forecast reduce more.

POST: Considering the instructions of companies' disclosure, enacted 2007 august, Chapter III, Section I, paragraph 7, deadline to forecast annual earnings per share at the end of each quarter, has increased from 20 days to 30 days. POST dummy variable was entered into the model to control for the effect of change in the deadline. The variable is equal to 1 , if the ending date of a quarter would be after the date the new instructions were approved, otherwise it equals zero.

INDUSTRY: Virtual variable for the industry a company belongs too. It shown that there are certain conventions among companies in each industry for their time of reporting (Givoly and Palmon, 1982). The industry categories used in this study are as follows: 1 . computer services and other services, 2. Automotive and transportation, 3. Chemical, 4. Food, 5. Drug, 6. Machinery and equipment; 7. Building construction, cement and other building materials; 8. Rubber and plastics; 9. Credit institutions; 10. Investment and holding; 11. Metallic and non-metallic minerals, basic metals, and metal products.

\section{Results}

Table 1 shows how the available population has been formed out of the target population. 
Table 1. The steps to form the available population

\begin{tabular}{|l|c|}
\hline Forecasts announced over 2004 to 2010. & 9114 \\
\hline $\begin{array}{l}\text { Remaining forecasts after removal } \\
\text { of the firm-years not having a three- } \\
\text { month, a six-month and a nine-month } \\
\text { forecast }\end{array}$ & 5845 \\
\hline $\begin{array}{l}\text { Remaining forecasts after removal of } \\
\text { the firm-years having additional forecast } \\
\text { between quarterly forecasts. }\end{array}$ & 4547 \\
\hline $\begin{array}{l}\text { Remaining forecasts after removal of } \\
\text { the firm-years having forecasts within } \\
\text { two months before 3-month forecasts. }\end{array}$ & 1872 \\
\hline $\begin{array}{l}\text { Remaining forecasts after removal of } \\
\text { the firm-years having increase in capi- } \\
\text { tal during the investigated year. }\end{array}$ & 1551 \\
\hline $\begin{array}{l}\text { Remaining forecasts after omitting the } \\
\text { firm-years due to lack of other data. }\end{array}$ & 1320 \\
\hline
\end{tabular}

Based on data recorded in the Rahavard Novin software there was a total number of 9114 announced forecasts for the firm-years that the end of their fiscal year was between 2004 to 2010, that after refining data based on the predetermined criteria, finally, remains 1320 observations from 440 firm-years and from 236 companies, which form the available population for this study.
Only firms that have issued 3, 6 and 9 month forecasts, have been selected so that the analysis would be based on the firms which comply with the instructions mandated by the authorities in Tehran Stock Exchange. The second and the third conditions are set so that additional recent forecasts between the standard forecasts may affect the pattern being studied.

The number of firm-years in the sample to examine the hypothesis equals to 400 firm-years, including 1200 observations ( a 3 month, a 6 month and a 9 month observations for each firm-year). Using systematic random method the sample was selected out of the available population. Then, using SPSS software, a linear regression (Enter method) was run on the data. Based on preliminary results, the data contain a standard deviation more than 3 , in the curve of distribution of residuals of the model were considered outliers and removed and the regression was run again. After repeating this process several times, the final sample obtained includes 1160 records, which was used to test the hypothesis.

\subsection{Descriptive data}

Tables 2 and 3 provide descriptive statistics for the variables used. After removal of outliers, the number of observations remaining to run the final regression and test the hypothesis was 1160 observations.

Table 2. Descriptive statistics of quantitative variables in the model

\begin{tabular}{|c|c|c|c|c|}
\hline Variable & Mean & Standard deviation & Minimum & Maximum \\
\hline DELAY & 40.38 & 18.61 & 3 & 103 \\
\hline GOOD*\% $\%$ EPS & 0.09 & 0.73 & 0 & 18.22 \\
\hline $\mathrm{BAD} * \% \Delta \mathrm{EPS}$ & -0.13 & 1.12 & -28.37 & 0 \\
\hline$\%$ COVER & 0.38 & 1.09 & -25.03 & 17.33 \\
\hline SHARE & 12.56 & 2.53 & 3.00 & 19.08 \\
\hline SIZE & 25.52 & 1.40 & 17.93 & 30.62 \\
\hline $\mathrm{BLOCK} \%$ & 0.7440 & 0.1887 & 0 & 0.9931 \\
\hline \multicolumn{5}{|c|}{ Number of observations: 1160} \\
\hline
\end{tabular}

Table 3. Descriptive statistics of dummy variables in the model

\begin{tabular}{|c|c|}
\hline Variable & $\begin{array}{c}\text { Frequency } \\
\text { of }(1)\end{array}$ \\
\hline BAD & 198 \\
\hline CONSOLIDATE & 337 \\
\hline LOSS & 42 \\
\hline POST & 799 \\
\hline \multicolumn{2}{|c|}{ Number of observations: 1160} \\
\hline
\end{tabular}

As shown in Table 4, F statistic is 8.930 and significance level less than 0.001 that confirms adequacy of the model at a level of higher than $95 \%$ confidence. Accordingly, it can be accepted that the model is capable of explain (at least, part of) changes in the dependent variable by Independent variables.

The adjusted $\mathrm{R}$ square statistic shows that the model variables, in total, have power to determine $12 \%$ of the dependent variable variability. Thus, set of present affecting of the influencing independent variables present in the 
Table 4. Model Summary

\begin{tabular}{|c|c|c|c|c|c|}
\hline F statistic & Correlation coefficient & $(\mathrm{R} 2)$ & Adjusted R2 & Std. Error of the Estimate & Durbin-Watson \\
\hline $\begin{array}{c}8.930 \\
(0.000) *\end{array}$ & 0.368 & 0.136 & 0.120 & 17.456 & 1.640 \\
\hline \multicolumn{6}{|c|}{$*$ Significance level less than 0.001} \\
\hline
\end{tabular}

final model, all together, explain $12 \%$ of changes in the DELAY variable.

Table 5 shows coefficients obtained by the model fitted by regression for the association between delay variable and the predicting variables. Positive coefficient of 11.67 for the BAD variable shows that firms going to announce negative adjustments in the previous forecasted EPS, on average, have nearly 12 more days delay in announcing of that EPS forecast. This result is consistent with the pattern of good news, early, bad news, late. T-statistic is equal to 8.869, (significance level less than 0.001) that this result confirms our finding with less than one percent probability of error, and thus with more than $95 \%$ probability of confidence. Thus, the research hypothesis accepted; in other words, there is a significant positive relationship between the type of earnings news, and the amount of delay in announcing quarterly forecasts of annual earnings.

Significant negative coefficient at 0.08 level for the interaction of bad news with the adjustment percentage (BAD*\% $\%$ EPS) Shows that the magnitude of adjustments has a negative relation with the delay in announcing that adjustment; so that, the larger negative adjustments are announced earlier than smaller negative adjustments.

Coverage percentage variable (\%COVER) with -1.143 coefficient indicated that higher coverage percentage, as a criterion of company's successful performance, causes the delay in announcing the EPS forecast to be decreased. The p-value is equal to 0.017 that shows the alpha error prob-

Table 5. Coefficients

\begin{tabular}{|l|c|c|c|c|}
\hline Model variables & Expected sign & coefficient & t-statistic & Sig. \\
\hline Constant & + & 24.84 & 2.46 & 0.01 \\
\hline BAD & + & 11.67 & 8.14 & 0.00 \\
\hline GOOD*\% $\Delta$ EPS & $-/+$ & 0.96 & 1.35 & 0.18 \\
\hline BAD*\% $\Delta$ EPS & $-/+$ & -0.90 & -1.75 & 0.08 \\
\hline \%COVER & - & -1.143 & -2.396 & 0.017 \\
\hline SHARE & - & 0.239 & 0.985 & 0.325 \\
\hline SIZE & + & 0.094 & 0.213 & 0.831 \\
\hline BLOCK\% & - & 3.387 & 1.085 & 0.278 \\
\hline CONSOLIDATE & + & 1.964 & 1.486 & 0.137 \\
\hline LOSS & + & 6.307 & 1.981 & 0.048 \\
\hline POST & + & -2.219 & -1.883 & 0.060 \\
\hline Computer services and other services & $-/+$ & 9.164 & 2.478 & 0.013 \\
\hline Vehicles and Transportation & $-/+$ & 7.552 & 3.511 & 0.000 \\
\hline Chemical & $-/+$ & 2.793 & 1.341 & 0.180 \\
\hline Food & $-/+$ & 12.254 & 5.622 & 0.000 \\
\hline Machinery and equipment & $-/+$ & 10.072 & 4.439 & 0.000 \\
\hline construction, cement & $-/+$ & 11.359 & 5.848 & 0.000 \\
\hline Rubber and plastic & $-/+$ & 1.912 & 0.613 & 0.540 \\
\hline Credit institutions and ... & $-/+$ & 8.141 & 1.838 & 0.066 \\
\hline Investment and holding & $-/+$ & 1.896 & 0.731 & 0.465 \\
\hline Metallic, non-metallic, minerals ... & $-/+$ & 7.463 & 4.047 & 0.000 \\
\hline & & & & \\
\hline
\end{tabular}


ability in rejecting the correct null hypothesis was less than $2 \%$. Thus with more than 95 percent confidence it can be said, there is such a relationship.

Consistent with initial expectations and previous studies, the positive coefficient of 6.307 for the LOSS variable shows that companies announcing loss per share, have on average, an additional delay of about 6 days. Significance level of 0.048 provides more than $95 \%$ confidence in the influence of this variable.

Coefficient -2.219 for the POST variable is opposite to the expectations, because it was expected that increase in announcement deadline from 20 days to 30 days, would increase the delay in announcing the quarterly forecasts of annual earnings (a positive coefficient for this variable). The resulting coefficient can be interpreted this way that basically, in recent years due to reasons such as technology advances and the increasing importance of timely reporting, delay in reporting forecasts has been reduced. With this interpretation, POST variable shows that over time the behavior of companies in announcing earnings has been changed. However, at the significance level of 0.06 , the reliability of this result can be little reduced.

Significance of seven variables for different industries indicates that consistent with the results of previous studies, at least in some industries, there is a special time convention for announcing earnings, and/or managers in a particular industry try to release their EPS forecasts when their colleagues do that.

Also in investigated assumptions underlying the regression, to rely on the obtained results, it was clear that the Durbin-Watson statistic is equal to 1.640 . Because of its proximity to number 2 , it can be confirmed that the residuals are independent. In the Scatter plot of the standardized residuals against standardized predicted values, no trend is observed and the observations symmetry is around point zero, thus the residuals variances are homogeneous. The residuals distribution histogram and p-p plot chart show that the residuals distribution is normal, and eventually, according to the use of several independent variables, the amount of VIF statistic is less than 10 and the amount of Tolerance is approximately 1 that indicate there is no multiple colinearity between the variables.

\section{Conclusion}

In this study, we studied the relationship between news type and the amount of delay in announcing the news, In the case of quarterly forecasts of annual earnings. The initial expectation was that consistent with the pattern of "good news early, bad news, late", negative EPS adjustments are announced with more delay. In accordance with results of previous studies, it became clear that there is an inverse relationship between the news type and the amount of delay in announcing the news of quarterly forecasts of annual earnings, So that firms with negative adjustments in EPS forecasts, on average, have approximately 12 days further delay in announcing the forecast. Furthermore, it became clear the magnitude of negative adjustments has a negative relation with the amount of delay in announcement. Examining other variables showed that with increasing the coverage percentage, as a sign of success of company performance, the amount of delay in announcing forecasts decreases. However, companies that announce losses per share, on average, have an additional delay of about 6 days. The results obtained also indicate that in some industries, there is a special time for reporting. Finally, it found that that in the period after the adoption of new disclosure instruction in TSE, despite increasing the deadline, delay in announcing quarterly forecasts of annual earnings has decreased, on average, by about 2 days. These findings could help regulators for setting better regulations in the capital market. We showed that managers have a socalled opportunistic strategy for announcing their earnings news. A reason for this behavior could be trying to attract less attention to bad news and avoid its undesirable consequences. What is their real intention and whether this strategy is successful to reach that goal, could be the subject for further research. It seems the results would be different based on the degree of efficiency of the market.

\section{References}

Aubert, F. (2009). Determinants of corporate financial disclosure timing: the French empirical evidence, Journal of Accounting and Taxation, 1(3), 053-060. Available at http://www.academicjournals.org/jat

Bagnoli, M., Clement, M. \& Watts, S. G. (2006). Around-the-Clock Media Coverage and the Timing of Earnings Announcements, McCombs Research Paper Series No. ACC-02-06.

Bagnoli, M., Kross, W. \& Watts S. (2002). The information in managements expected earnings report date: A day late, a penny short, Journal of Accounting Research, 40(5), 1275-1296. http://dx.doi.org/10.1111/1475-679X.t01-1-00054

Beaver, W.H. (1968), The Information Content of Annual Earnings Announcements, Empirical Research in Accounting: Selected Studies, pp. 67-92. Available at: http://www.jstor.org/ stable/2490070?seq $=1$

Begley, J., P. \& Fischer, E. (1998). Is there Information in an Earnings Announcement Delay?, Review of Accounting Studies, 3, 347363.

Bushee, B., Matsumoto D. \& Miller G. (2003). Open versus closed conference calls: The determinants and effects of broadening access to disclosure, Journal of Accounting and Economics, 34, 149-169. http://dx.doi.org/10.1016/S0165-4101(02)00073-3

Chambers, A. E. \& Penman S. H. (1984). Timeliness of reporting and stock price reaction to earnings announcements. Journal of Accounting Research, 22(1), 21-47. Available at: http://www. jstor.org/stable/2490700

Chen, C. R. \& Mohan, N. J (1994), Timing the Disclosure of Information: Management's View of Earnings Announcements, Financial Management, 23(3), 63.

Cullinan, C. P., Wang, F., Yang, B. \& Zhang, J. (2012). Audit opinion improvement and the timing of disclosure. Advances in Accounting, 28(12), 333-343. http://dx.doi.org/10.1016/j. adiac.2012.09.010

Damodaran, A., (1989), The weekend effect in information releases: A study of earnings and dividend announcements. Review of Financial Studies, 2(4), 607-623. 
Doyle, J. T. \& Magilke, M. J. (2012), The Strategic timing of management forecasts. Working paper, Utah State University. Available at: http://dx.doi.org/10.2139/ssrn.1479867

Givoly, D. \& Palmon D. (1982). Timeliness of annual earnings announcements: Some empirical evidence. The Accounting Review, 57, 486-508.

Guay, W. \& Verrecchia, R.E, (2007). Conservative disclosure. Working paper, University of Pennsylvania. Available at: http:// dx.doi.org/10.2139/ssrn.995562

Haw, I., Park K. J. \& Wu D. (2006). Securities Regulation, the Timing of Annual Report Release, and Market Implications: Evidence from China, Journal of International Financial Management and Accounting, 17(2), 111-139, http://dx.doi. org/10.1111\%2Fj.1467-646X.2006.00123.x

Haw, I.-M., Qi, D. \& Wu, W. (2000). Timeliness of Annual Report Releases and Market Reaction to Earnings Announcements in an Emerging Capital Market: The Case of China, Journal of International Financial Management \& Accounting, 11(2), 108131. http://dx.doi.org/10.1111/1467-646X.00058

Kross, W. (1981). Earnings and announcement time lags, Journal of Business Research, 9(3), 267-281, http://dx.doi. org/10.1016/0148-2963(81)90021-7

Kross, W. (1982). Profitability, Earnings Announcement Time Lags, and Stock Prices. Journal Of Business Finance and Accounting, 9(3), 313-28. http://dx.doi.org/10.1111\%2Fj.1468-5957.1982. tb00997.x

Kross, W. \& Schroeder, D. A. (1984). An empirical investigation of the effect of quarterly earnings announcement timing on stock returns. Journal of Accounting Research, 22 (1), 153-176, http:// dx.doi.org/10.2307\%2F2490706

Moayyeri, M. (2007). Factors affecting audit report timeliness, MSc dissertation, Allame Tabataba'I University, Iran.

Moradi, M. \& Poor Hosseini, S.M. (2009). Examining the association between some financial and nonfinancial features and the time for conducting and finishing audit in TSE listed companies, Iranian Accounting Research, 1, 166-185.

Patell, J. M. \& Wolfson, M. (1982). Good News, bad news, and the intraday timing of corporate disclosures. The Accounting Review, 57(3), 509-527.

Philipich, K. L. (2009). Changes in the Disclosure Regulatory Environment and Managers' Timing of Earnings Announcements, Journal of American Academy of Business, 15(1), 24-31.
Roychowdhury, S. \& Sletten, E. (2012). Voluntary Disclosure Incentives and Earnings Informativeness. The Accounting Review, 87(5), 1679-1708, http://dx.doi.org/10.2308/accr50189

Sarhangi, H. (2001). Examining the factors influencing annual reporting timeliness of companies in Tehran stock exchange during 1995 to 1999. Msc dissertation. Tarbiat Moderress University, Iran.

Sengupta, P. (2004). Disclosure timing: Determinants of quarterly earnings release dates, Journal of Accounting and Public Policy, 23, 457-482, http://dx.doi.org/10.1016/j.jaccpubpol.2004.10.001

Skinner D. (1994). Why Firms Voluntarily Disclose Bad News. Journal of Accounting Research, 32(1), 38-60, http://dx.doi. org/10.2307\%2F2491386

Tehran Stock Exchange instruction for information disclosure by Listed companies, 2002 (modified: 2007). Available at: http:// www.tse.ir/

Yaar Mohammadi, A., (2001). Examining determinants of timely interim reporting in Tehran Stock Exchange listed companies, MSc dissertation, Tarbiat Moderress University, Iran.

Mahdi Moradi is an Associate Professor of Accounting, Ferdowsi University of Mashhad, Iran, He has more than 20 years academic experiences in Iran. So far, he has published more than 27 papers in international journals and 12 papers in national journals in Persian. His research interests include financial reporting, ERP and auditing.

Mahdi Salehi is an Assistant Professor of Accounting, Ferdowsi University of Mashhad, Iran. He has more than 8 years of academic experience. So far, he has published more than 165 papers in international journals, his interests include: auditing, audit expectation gap, and financial distress prediction.

Seyyed Saeed Mehrdad Ayask has obtained his M.A in Accounting from the Ferdowsi University of Mashhad, Iran. Currently he is doing his PhD in Accountancy at the Isfahan University, Isfahan, Iran. 